\title{
Sir John James Burnet, R.A., R.S.A., LL.D.(Glas.), F.S.A., F.R.I.B.A.
}

SIR JOHN J. BURNET was the son of an eminent Glasgow architect of the latter decades of the nineteenth century-John Burnet-and became a partner in the firm known for many years as John Burnet \& Son. He was born in 1857 in Glasgow and died in Edinburgh on July 2, I938.

Destined from boyhood to follow his father's profession, he had his preliminary training in the drawing-office of his father after leaving school in Glasgow. After a period he was sent to Paris to continue his artistic and architectural training. There he worked firstly in the studio of Monsieur Pascal and was later admitted to the Ecole des Beaux Arts, where he gained two medals-for mathematics and construction. On returning to Glasgow he resumed work with his father and gained an almost immediate success in a competition for the Galleries of the Royal Glasgow Institute of the Fine Arts. Following this he became increasingly active on succeeding his father, and was responsible for many important buildings in Scotland. Among his principal works are, in Glasgow, the Clyde Trust Offices, extensions to the University and to the Western Infirmary, the Elder Library and the Elder Cottage Hospital in Govan, the Barony Church and the Stock Exchange extensions. Buildings erected after his designs in Edinburgh are the former Professional and Civil Service Stores in George Street, Messrs Forsyth's premises in Princes Street, and the Head Offices of the Union Bank of Scotland, Glasgow. In other parts of Scotland he was responsible for the Gardner Memorial Church, Brechin; the Town Church, Arbroath; the M'Laren Memorial Church, Stenhousemuir; and the restoration of Duart Castle, Mull.

His appointment to be the architect of the King Edward VII Galleries, British Museum extension in 1905, led to many other commissions in the South and was instrumental in the principal offices of the firm being transferred to London. Among his more important works in the capital are the Institute of Chemistry in Russell Square, the Kodak Building in Kingsway, the General Accident Building in Aldwych, Selfridge's extension in Oxford Street, and the conspicuous Adelaide House at London Bridge.

After the war of 1914-18 he was appointed chief architect for the 
Imperial War Graves Commission in Palestine and Gallipoli. As senior member of the London firm of Sir John Burnet, Tait and Lorne he gradually retired from business activities and eventually returned to Edinburgh a few years ago, after having lived at Farnham, Surrey.

Sir John was elected a Royal Scottish Academician in 1914 and received a knighthood in the same year, in 1923 the Royal Gold Medal of the Royal Institute of British Architects was conferred on him, and in 1925 he was elected a Member of the Royal Academy. He was an Honorary LL.D. of Glasgow University, a Fellow of the Royal Society of Edinburgh (elected I 887) and a Corresponding Member of the Institut de France, as also of the American Institution of Architects.

Sir John Burnet must be considered as one of the most important architects of this period of transition from the comfortable complacency of the later Victorian decades to the troubled post-war reactions that tend towards a denial of all but functional requirements. The mind of the sensitive and restrained artist, more prominent in the results of his earlier efforts, is nevertheless ever present in the later works in which the more rigid requirements of the times have been dictated to the architect.

In the words used in connection with the conferring of the Gold Medal in I923, "few architects may be said to have so pervasive an effect on the work of their own time."

Sir John married in 1886 Jean Watt, daughter of the late Sir James Marwick, who was Town Clerk of Glasgow for many years. $\mathrm{He}$ is survived by Lady Burnet and had no family.

A. E. H. M. 